\title{
Yield, water use efficiency and crop co-efficient of cucumber (Cucumis sativus L.) grown under greenhouse and open field condition
}

\author{
K. Arunadevi*, A.D. Ashok ${ }^{1}$ and E. Sujitha ${ }^{1}$ \\ Department of Soil and Water Conservation Engineering, Agricultural Engineering College and Research Institute, \\ Tamil Nadu Agricultural University, Kumulur, Trichy (T.N.) India \\ (Email: arunadeviswce@gmail.com)
}

\begin{abstract}
A field experiment was conducted with Chitra variety of cucumber at Agricultural Engineering College and Research Institute, Tamil Nadu Agricultural University, Kumulur in the year 2019-2020. The cucumber seeds were sown under greenhouse and open field condition under drip irrigation system. The micro climatic parameters like maximum and minimum temperature, relative humidity, light intensity were observed. Cucumber plant growth parameters, yield parameters and water use efficiency were recorded. Early flowering and fruit formation (32 days after sowing) was noticed inside greenhouse condition and fruit formation was noticed 40 days after sowing in out-side cultivation. The average length of the fruit was found $20.5 \mathrm{~cm}$ inside greenhouse and $17.6 \mathrm{~cm}$ for outside cultivation of cucumber. A maximum yield of $11.6 \mathrm{t} / \mathrm{ha}$ was recorded inside greenhouse cultivation whereas $7.84 \mathrm{t} / \mathrm{ha}$ was recorded for outside cultivation of cucumber. The water use efficiency of $25.7 \mathrm{~kg} / \mathrm{ha}$. $\mathrm{mm}$ was obtained under green house cultivation whereas water use efficiency of $16.70 \mathrm{~kg} / \mathrm{ha} . \mathrm{mm}$ was recorded in open field cultivation. The crop co-efficient value of $0.67,0.87,1.12$ and 0.89 were developed for initial, developmental, middle and end stages of crop growth period for open field cultivation. Similarly crop co-efficient value of $0.63,0.82,1.05$ and 0.88 were developed for initial, developmental, middle and end stages of crop growth period for polyhouse condition of semi arid region.
\end{abstract}

Key Words : Cucumber, Greenhouse, Water use efficiency, Micro climatic parameters

View Point Article : Arunadevi, K., Ashok, A.D. and Sujitha, E. (2021). Yield, water use efficiency and crop co-efficient of cucumber (Cucumis sativus L.) grown under greenhouse and open field condition. Internat. J. agric. Sci., 17 (2) : 141-145, DOI:10.15740/HAS/IJAS/ 17.2/141-145. Copyright@2021: Hind Agri-Horticultural Society.

Article History : Received :21.02.2021; Revised : 28.02.2021; Accepted : 13.03.2021

\footnotetext{
*Author for correspondence:

${ }^{1}$ Institute of Agriculture, Tamil Nadu Agricultural University, Kumulur, Trichy (T.N.) India
} 